\title{
Indigestible Foreign Bodies in the Rumen-reticulum of Cattle Slaughtered at Batna Slaughterhouse, Algeria: A Postmortem Study
}

\begin{abstract}
Background: To determine the prevalence of indigestible foreign bodies in rumen-reticulum of cattle and identify the types and the common diseases associated with their occurrence. A total of 289 cattle were examined at Batna (Algeria) municipal abattoir. Methods: About 289 cattle were examined immediately after slaughtering to determine the presence or absence of the foreign bodies in their rumen-reticulum and different lesions were recorded.

Result: From total of 289 cattle examined, 151 (52.24\%) were found positive for various types of foreign bodies in their rumen and/ or reticulum. From these, 56 (19.37\%) were positive for vulnerable bodies and 95 (52.24\%) were positive for non-vulnerable foreign bodies. The types of foreign bodies detected were: wire segments, needles, nails, hair clips, coins, corks, ropes, cloth, pebbles, sand, glass pieces, trichobezoar, plastic bags. The plastics were the most common found in $61(23.92 \%)$ males and $34(79.06 \%)$ females. The most common lesions in rumen of cattle with foreign bodies were traumatic reticuloperitonitis $(3.79 \%)$, perirecticular abscess $(12.65 \%)$, esophageal obstruction $(1.26 \%)$, non-penetrating reticulum and/or ruminal foreign bodies $(82.27 \%)$.
\end{abstract}

Key words: Cattle, Foreign bodies, Lesions, Prevalence, Traumatic reticuloperitonitis.

\section{INTRODUCTION}

The ingestion of foreign bodies is mainly related to nutritive deficiency and feeding management of the animals and causes various problem such as; glositis, esophagitis, ruminitis, impaction of rumen, traumatic pericarditis (TP) and traumatic reticulo peritonitis (TRP) are the possible health problems can be caused by the ingestion of foreign bodies by ruminants. Among these, disease of rumen and reticulum are of great economic importance because of severe losses on productivity of the animals sometimes leading to the death of the animals (McCurin and Basser, 2006; Tesfaye and Mersha, 2012; Abu-Seida and Al-Abbadi, 2016).

Entrance and migration of foreign bodies through the body tissues lead to many complication that differ according to the nature of the foreign body and the way of its entrance in to the tissues (Semieka, 2010). Traumatic reticulo peritonitis (TRP) relatively common disease in cattle caused by the ingestion of vulnerable objects such as nail or pieces of wire who fall directly on the reticulum or pass into the rumen and subsequently carried over the rumeno-reticular folds into the cranioventral part of the reticulum (McCurin and Basser, 2006; Braun et al. 2007). Non-vulnerable foreign bodies in the reticulo-rumen cause recurrent rumen tympany in cattle, trichobezoars (a mass found trapped in the gastrointestinal system) have been found associated with acute rumen tympany in calves and young cattle (Maxie, 2007; Vanitha et al. 2010). Over a period of time, these materials form large tight balls inside the rumen lead to anorexia, decreased production and progressive loss of body condition (Tyagi and Singh, 1993). It was reported that a large proportion of cattle with non-vulnerable foreign bodies (plastics) in the rumen had displacement of abomasum and a decrease in milk production (Al-Majali et al.
Department of Veterinary, Laboratory of Environmental Health and Animal Production, University Hadj Lakhder Batna1, 05000 Algeria.

Corresponding Author: Rouabah Zahra, Department of Veterinary, Laboratory of Environmental Health and Animal Production, University Hadj Lakhder Batna1, 05000 Algeria.

Email: zohra.rouabah@univ-batna.dz

How to cite this article: Rouabah, Z., Tlidjane, M., Hafid, N. (2021). Indigestible Foreign Bodies in the Rumen-reticulum of Cattle Slaughtered at Batna Slaughterhouse, Algeria: A Postmortem Study. Agricultural Reviews. DOI: 10.18805/ag.RF-222.

Submitted: 10-09-2021 Accepted: 25-11-2021 Online: 22-12-2021

1995), rumenitis, erosion and focal hyperplasia (Hailat et al. 1998).

In Algeria, extensive and semi-intensive livestock management systems are mostly practiced in both rural and urban areas. This makes the livestock prone to refusedumping areas where they have access to polythene and other indigestible materials. Deficiency of some minerals led these animals to pick up these materials, probably containing some food materials, in other to make up for deficiencies or satisfy their hunger (Misk et al. 1984). This study was carried out in order to study a postmortem on indigestible foreign bodies and the associated lesions in the rumen and reticulum of cattle.

\section{MATERIALS AND METHODS}

\section{Study area}

The study was conducted in Batna City, north eastern Algeria, Batna is located between the north and south Atlas Mountains which rise on either side to form a sort of naturally 
protective passage over the province. The climate tends to vary quite widely; with extreme heat during the summer and snow and cold during the winter. The latitude and longitude of Batna City are $7^{\circ}-4^{\circ} \mathrm{N}$ and $35^{\circ}-36^{\circ} \mathrm{E}$, respectively. The average altitude of the city is 1,048 meters above sea level with a temperature range of $4^{\circ}$ to $35^{\circ} \mathrm{C}$ according to the management of agricultural services (2021). Batna has livestock population of 65052 cattle, 275664 goats, 1137361 sheep.

\section{Animals}

The study was conducted on 298 apparently healthy cattle (245 males and 43 females), slaughtered at Batna Municipal Abattoir between January and July 2021. The animals for slaughter were coming from different areas surrounding the town. Cattle presented for slaughter were identified by sex, age and race. Age was determined based on dental eruption as previously described by Otesile and Obasaju (1982). After slaughter of the animals the rumen and reticulum were examined in the evisceration stage, they were opened and any foreign bodies were washed with water to removing adhering feed material and identified. The plastics and/or other foreign bodies collected from each animals were separated into different types and different lesions were recorded.

\section{RESULTS AND DISCUSSION}

\section{Prevalence of foreign body in cattle}

A total of 151 out of 298 animals (50.67\%) examined were found to be positive for different types of foreign bodies. The extracted foreign bodies were categorized into two main groups: vulnerable foreign bodies (VFB) ( $n=56,19.19 \%)$ and the non-vulnerable foreign bodies (NVFB, $\mathrm{n}=95$, $21.87 \%$ ) (Table 1).

Cattle with foreign body is one of the most commonly occurring problems of the digestive tract of ruminants (Aref and Abdel-Hakiem, 2013) and reported from Jordan, (Majali et al.1995) Pakistan (Jan Mohammad Khan et al.1999), Nigeria (Igbokwe, 2003 ; Remi-Adewunmi et al.2004), Sudan (Mohammed et al.2006; Ghurashi , 2009; Khurshaid et al. 2013), India (Vanitha et al. 2010 ; Hussain and Uppal, 2012; Rajput et al. 2018), Germany (Bhatt et al. 2011) Rwanda (Mushonga et al. 2015) , Iraq (Abu-Seida, 2016) and Algeria (Rouabah et al. 2017). More or less consistent overall foreign body prevalence of $59.14 \%$ was reported by Khurshaid et al.(2013) in Pakistan, 43.4\%,41.8\% and $23.9 \%$ were reported by Sheferaw et al. (2014), Negash et al.(2015), and Dawitet al.(2012) in Ethiopia respectively, $38.6 \%$ and $12 \%$ were reported by Ngoshe (2012)and Akinbobola et al.(2016) in Nigeria and $17.4 \%$ by Mushonga et al.(2015) in Rwanda. The present study revealed an overall prevalence of $50,67 \%(n=298)$ of foreign bodies, consisting mainly of plastics, in rumen and reticulum of cattle slaughtered at Batna municipal abattoir. The prevalence of rumen-reticulumforeign bodies in the current study is substantially higher in the cattle population (Hussain and Uppal, 2012) compared to results published in other countries (Fraser and Broom, 1990). The higher prevalence of foreign bodies in the current study probably is related to the unrestricted and increased use of plastic bags and their improper disposal. Ingestion of foreign bodies is associated with a shortage of forage (Hailat et al. 1996) as well as increased pollution of grazing lands with indigestible materials (Tesfaye et al. 2012). If owners do not provide supplementary feed during feed shortages, their animals are likely to face a negative energy balance that will force them to ingest unusual materials including plastic, cloth, rope and even metallic objects (Negash et al. 2015). Ingestion of foreign bodies is common in cattle because of indiscriminate feeding habits and the anatomical features of the buccal cavity. Both hard and soft objects are ingested accidentally by cattle; the hard objects usually go straight into the reticulum while the soft ones find their way to the rumen (Misk et al.1984).

From 255 males and 43 females animals examined, foreign body was found in the rumen of 114 males (75.49 $\%$ ) and 37 females (24.50\%) (Table 2). The incidences of ingestion of foreign bodies were low in females compared to males and this may be due to the low number of females slaughtered than the males (Rouabah et al. 2017). Further, the females generally have a longer lifespan than males and livestock farmers normally do not sell females because they reproduce and increase the herd size. The findings of the present work are in agreement with the earlier report published wherein the differences in prevalence rates observed in males 155 (23.8\%) and females 114 (22.7\%) cattle (Mekuanint et al.2017) and not in agreement with the results published by Mushonga et al. (2015), Akinbobola et al. (2016), Kassahu and Tesfaye (2017) who reported foreign bodies more in female cattle $(20.0 \%),(18.42 \%),(17.22 \%)$ than males. (15.7\%), (8.06\%) and (17.15\%) respectively.

\section{Particulars of foreign bodies found in the rumen-reticulum}

The first category of encountered foreign bodies is foreign bodies of metallic origin and, their frequency of occurrence

Table 1: Prevalence of different types of foreign bodies extracted from positive animals slaughtered at Batna Municipal Abattoir.

\begin{tabular}{lccc}
\hline $\begin{array}{l}\text { Animals } \\
\text { examined }\end{array}$ & $\begin{array}{c}\text { Positive } \\
\text { animals with } \\
\text { foreign bodies }\end{array}$ & $\begin{array}{c}\text { Positive } \\
\text { animals with } \\
\text { VFB }\end{array}$ & $\begin{array}{c}\text { Positive } \\
\text { animals with } \\
\text { NVFB }\end{array}$ \\
\hline 298 & 151 & 56 & 95 \\
Prevalence (\%) & $50.67 \%$ & $18.79 \%$ & $21.87 \%$ \\
\hline
\end{tabular}

Table 2: Sex distribution of rumen FBs in cattle slaughtered at Batna Municipal Abattoir.

\begin{tabular}{lccc}
\hline $\begin{array}{l}\text { Sex of } \\
\text { animals }\end{array}$ & $\begin{array}{c}\text { Number of } \\
\text { examined } \\
\text { animals }\end{array}$ & $\begin{array}{c}\text { Number of } \\
\text { positive animals } \\
\text { Withforeign bodies }\end{array}$ & $\begin{array}{c}\text { Prevalence } \\
(\%)\end{array}$ \\
\hline Male & 255 & 114 & $75.49 \%$ \\
Female & 43 & 37 & $24.50 \%$ \\
Total & 298 & 151 & $50.67 \%$ \\
\hline
\end{tabular}


are presented in Table 3. The foreign bodies detected were nails $(26.79 \%)$, wire segment $(25 \%)$, non-differentiated foreign bodies $(17.85 \%)$, magnet $(14.28 \%)$, bottle cops $(10.71 \%)$, needles $(3.58 \%)$ and hair clips (1.79 \%).

The second category is foreign bodies of non metallic origin such as plastic bags $(54.73 \%)$, glass $(10.53 \%)$, rope $(9.47 \%)$, caps $(8.42 \%)$ and piece of cloth $(45.27 \%)$ were the most frequent encountered foreign body types (Table 4).

Most of them are ingested accidentally but sometimes animals intended to prehend them to overcome nutritional deficiencies they suffer .Varieties of foreign bodies depend

Table 3: Frequency of occurrence of rumen vulnerable foreign bodies (VFB) encountered in cattle.

\begin{tabular}{lcc}
\hline Type of FB & $\begin{array}{c}\text { Number } \\
\text { of } \\
\text { VFB }\end{array}$ & $\begin{array}{c}\text { Frequency of } \\
\text { occurrence } \\
\text { (\% of animals) }\end{array}$ \\
\hline Wire segment & 20 & $14(25 \%)$ \\
Needles & 02 & $02(3.58 \%)$ \\
Nails & 15 & $15(26.79 \%)$ \\
Hair clips & 02 & $01(1.79 \%)$ \\
Bottle cops & 06 & $06(10.71 \%)$ \\
Non differentiated foreign bodies & 10 & $10(17.85 \%)$ \\
Magnet & 08 & $08(14.28 \%)$ \\
Total & 63 & 56 \\
\hline
\end{tabular}

Table 4: Frequency of occurrence of rumen non-vulnerable foreign bodies (NVFB) encountered in cattle.

\begin{tabular}{lcc}
\hline Type of FB & $\begin{array}{c}\text { Number } \\
\text { of } \\
\text { NVFB }\end{array}$ & $\begin{array}{c}\text { Frequency of } \\
\text { occurrence } \\
\text { (\% of animals) }\end{array}$ \\
\hline Plastic bags & 50 & $52(54.73 \%)$ \\
Rope & 10 & $09(9.47 \%)$ \\
Piece of cloth & 05 & $05(5.27 \%)$ \\
Caps & 08 & $08(8.42 \%)$ \\
Stones & 03 & $03(3.16 \%)$ \\
Sand & 02 & $04(4.21 \%)$ \\
Glass & 10 & $10(10.53 \%)$ \\
Trichobezoar & 03 & $04(4.21 \%)$ \\
Total & 81 & 95 \\
\hline
\end{tabular}

Table 5: Illustration of different diseases caused by foreign bodies and number of affected cattle.

\begin{tabular}{|c|c|c|c|c|}
\hline $\begin{array}{l}\text { Type of } \\
\text { diseases }\end{array}$ & $\begin{array}{c}\text { Number of } \\
\text { examined } \\
\text { female }\end{array}$ & $\begin{array}{c}\text { Number of } \\
\text { examined } \\
\text { male }\end{array}$ & Total & $\begin{array}{c}\text { Prevalence } \\
\%\end{array}$ \\
\hline $\begin{array}{l}\text { Traumatic } \\
\text { reticuloperitonitis (TRP) }\end{array}$ & 03 & - & 03 & $3.79 \%$ \\
\hline Perireticulare abscess & 10 & - & 10 & $12.65 \%$ \\
\hline CEsophageal obstruction & - & 01 & 01 & $1.26 \%$ \\
\hline $\begin{array}{l}\text { Non-penetrating reticular } \\
\text { and/or ruminal foreign bodie }\end{array}$ & $\begin{array}{l}\text { ar } 15 \\
\text { dies }\end{array}$ & 50 & 65 & $82.27 \%$ \\
\hline Total & 28 & 51 & 79 & $\%$ \\
\hline
\end{tabular}

mainly on the surrounding environments where the animals were raised. Igbokwe et al. (2003) indicated that the metallic objects, dry seeds and ropes might be indiscriminately ingested when imbedded in other available palatable foods. Plastic was the most commonly encountered foreign material in all study animals, followed by cloth and ropes ( Tesfaye et al. 2012; Sheferaw et al. 2014; Negash et al. 2015 ; Igbokwe et al. 2003; Remi- Adewunmi et al. 2004, Akinbobola et al. 2016) and Hailat et al.2016).

This indicates the widespread use of plastic bags in these areas leading to environmental pollution due to their improper disposal, are non-biodegradable and are the most improperly disposed waste materials in the urban and suburban area (Akinbobola et al. 2016). The present study is contrary to the report of Ngoshe (2012) in Nigeria, who reported polythene bag as the only indigestible foreign material seen in cattle and of Khurshaid et al. ( 2013) in Pakistan who reported clothes have higher frequency of occurrence followed by plastics and nails.

\section{Different diseases caused by foreign bodies}

In the present study we found traumatic reticuloperitonitis $(3.79 \%)$ (TRP) perireticulare abscess (12.65\%), œsophageal obstruction (1.6\%) and reticular and / or ruminal foreign bodies $(82.27 \%)$.

TRP is relatively common disease in cattle caused by the ingestion and migration of vulnerable foreign bodies in the reticulum. This study was consistent with (Misk at al., 2001) who reported 32 cases of reticuloperitonitis (TRP), 6 perireticulare abscess and 32 reticular and /or ruminal foreign bodies (Table 5 ).

\section{CONCLUSION}

It is concluded that ingestion of foreign bodies is common in cattle slaughtered at Batna Municipal Slaughterhouse and play an important role not only in loss of cattle because of its high mortality and morbidity rates but also it contributes for reduced production and productivity. In order, to save the environment and free grazing ruminants, an appropriate solid waste disposal system need to implement to reduce the prevalence of foreign bodies in cattle and also to protect the environment. We concluded also that the presence of foreign bodies in the rumen - reticulum of cattle, depending on the quantity and duration, caused several complications mainly the rumen impaction, perireticulare abscess and traumatic reticuloperitonitis (TRP).

\section{REFERENCES}

Abu-Seida, A.M. (2016). Current status and prospect of ultrasonographic application in buffaloes. Asian Journal of Animal and Veterinary Advances. 11: 144-157.

Akinbobola, J.S., Omeje, J.N., Akinbobola, R.I., Ayoade, R.I., Ajagbe, O.A., Okaiyeto, S.O. (2016). Prevalence of indigestible foreign bodies in the rumen of cattle slaughtered at Gwagwalada Abattoir, Abuja, Nigeria. International Journal of Livestock Research. 6(6): 25-31. 
Aref, N.M. and Abdel-Hakiem, M.A.H. (2013). Clinical and diagnostic methods for evaluation of sharp foreign body syndrome in buffaloes. Veterinary World. 6(9): 586-591.

Bakhiet, N.O. (2008). Studies on the rumen pathology of Sudanese desert sheep in slaughter house. Sudan Sheep. Scientific Research and Essay. 3(7): 294-298.

Bhatt, R.H., Jingesh, B.P., Nisha, J. (2011). Surgical management of ruminal impaction due to non-penetrating foreign body syndrome in Kankrej cattle. International Journal of Agriculture and Veterinary Medical Sciences. 5: 477-480.

Braun, U., Lejeune, B., Schweizer, G., Puorger, M. and Ehrensperger, F. (2007). Clinical findings in 28 cattle with traumatic pericarditis. The Veterinary Record. 161: 558-563.

Tesfaye, D., Diriba, D., Birhanu, M and Amene, F. (2012).The Problem of environmental pollution as reflected in the fore stomach of cattle: A postmortem study in eastern Ethiopia. Global Journal of Environmental Research. 6 (2): 61-65.

Fraser, A.F. and Broom, D.M. (1990). Farm Animal Behavior and Welfare $3^{\text {rd }}$ ed, ELBS Bailliere Tindall, London. pp. 318-322.

Ghurashi, M.A.H., Seri, H.I., Bakheit, A.H. and Ashwag, E.A.M. (2009). Effect of surgical removal of foreign body from goat's rumen with special reference to the prevalence of foreign body in goats in Southern Darfur. Australian Journal of Basic and Applied Science. 3(2): 664-668.

Hailat, N., Al-Darraji, A., Lafi, S., Barakat, S.A.F., Al-Ani, F., ElMagrhaby, H., Al-Qudah, K., Gharaibeh, S., Rousan, M., Al-Smadi, M. (1998). Pathology of the rumen in goats caused by plastic foreign bodies with reference to its prevalence in Jordan. Small Ruminant Research. 30: 77-83.

Hailat, N., Nouh, S., Al-Darraji, A., Lafi, S., Al-Ani, F., Al-Majali, A. (1996). Prevalence and pathology of foreign bodies (plastics) in Awassi Sheep in Jordan. Small Ruminant Research. 24: 43-48.

Hussain, S.A. and Uppal, S.K. (2012). Rumen impaction in buffaloes a haemato-biochemical study. Indian Journal of Animal Sciences. 82(4): 369-373.

Igbokwe, I.O., Koloand, M.Y., Egwu, G.O. (2003). Rumen impaction in sheep with indigestible foreign body in the semi arid region of Nigeria. Small Ruminant Research. 49: 141-147.

Jan, M.K., Glulam, H., Mohammad, M.S. (1999). Prevalence of foreign indigestible materials in the reticulo-rumen of adult buffaloes. Pakistan Veterinary Journal. 19(4): 176-180.

Kassahu, B. and Wale, T. (2017). Study on rumen and reticulium foreign bodies in cattle slauthered at Wolaita Sodo municipal Abattoir, Ethoipia. International Journal of Advanced Multidisciplinary Research. 4(1): 11-19.

Khurshaid, A., Ikhwan, K., Asim, A., Muhammad, M., Anwarud, D., Yasir, A., Zubair, A. (2013). Prevalence of indigestible rumen and reticulum foreign bodies in Achai cattle at different regions of Khyber pakhtunkhwa, ARPN Journal of Agricultural and Biological Science. 8(8): 580-586.

Majali, A., Hailat, N., Nouh, S. and AL-Ani, F. (1995). Dismacement of abomasum in cattle: diagnosis and treatment. Al-Tabib AlBairati. 11: 61-64.

Maxie, G.M. (2007). Pathology of Domestic Animals $5^{\text {th }}$ ed. USA: Elsevier, pp: 88-112.

McCurin, D.M. and Basser, J.M. (2006). Clinical Text Book for Veterinary Technicians. $6^{\text {th }}$, Ed. Elsevier, pp: 224-244.
Mekuanint, S., Alemneh, T., Asredie, T. (2017). Indigestible rumen foreign bodies- Causes of rumen impaction in cattle, sheep and goats slaughtered at Addis Ababa Abattoir Enterprise, Ethiopia. Journal of Veterinary Science and Medicine. 5(1): 5.

Misk, N.A., Nigam, J.M., Rifat, J.F. (1984). Management of foreign body syndrome in Iraqi cattle. Agri Practice. 5: 19-21.

Misk, N., Semieka, M., Ali, S. (2001). Varieties and sequelae of ingested foreign bodies in buffalo and cattle. Assiut Veterinary Medical Journal. 46: 250-273.

Mohammed, A., Bakhiet, O., Hayder, A. (2006). Retrospective study on the prevalence of foreign body in goat's Rumen: Omdurman Province, Khartoum State, Sudan (19982002). Journal of Animal and Veterinary Advances. 5: 449-451.

Mushonga, B., Habarugira, G., Musabyemungu, A., Udahemuka, J.C., Jaja F.I., Pepe. D., (2015). Investigations of foreign bodies in the fore-stomach of cattle at Ngoma Slaughterhouse, Rwanda. Journal of the South African Veterinary Association. 86(1): Art. \#1233, 6 pages. http://dx.doi.org/10.4102/ jsava. v86i1.1233.

Negash, S., Sibhat, B., Sheferaw, D. (2015). A postmortem study on indigestible foreign bodies in the rumen and reticulum of ruminants, eastern Ethiopia, Onderstepoort. Journal of Veterinary Research. 82(1): 881.

Ngoshe, A. (2012). Incidence of polythene bag ingestion by ruminant animals at Maiduguri central abattoir. Ramat Journal for Management Science and Technology. 1(4): 12-16.

Otesile, E.B. and Obasaju, M.F. (1982). Relationship between age and rostral teeth development in Nigerian goats, in Proc. $3^{\text {rd }}$ Inter. Conf. on Goat Production and Disease, University of Arizona, vol. 10-15, pp. 349.

Remi-Adewunmi, B.D., Gyang, E.O. and Osinowo A.O. (2004). Abattoir survey of foreign body rumen impaction in small ruminants. Nigerian Veterinary Journal. 25: 32-38.

Rajput, P.K., Parikh, P.V., Parmar, J.J., Mehta, T.A. and Patil, D.B. (2018). Studies on foreign body syndrome in bovines of Anand district of Gujarat. Indian Journal of Animal Research. 52: 744-749.

Rouabah, Z., Tlidjane, M., Safsaf, B., Mallem, M. and Meziane, T. (2017). Hemato-biochemical profile in cattle with rumen impaction. Global Veterinaria. 18(4): 250-255.

Semieka, M.A. (2010). Radiography of unusual foreign body in ruminants. Veterinary World. 13: 473-475.

Sheferaw, D., Fikreysus, G., Metenyelesh, A., Tesfaye, D. and Ethana, D. (2014). Ingestion of indigestible foreign materials by free grazing ruminants in Amhara region, Ethiopia. Tropical Animal Health and Production. 46: 247-250.

Tesfaye, D. and Mersha, C. (2012). Study on Rumen and Reticulum Foreign Bodies in Cattle Slaughtered at Jimma Municipal Abattoir, South West Ethiopia. American-Eurasian Journal of Scientific Research, 7(4): 160-167.

Tyagi, R.S. and Singh, J. (1993). Hernia Ruminant's Surgery. $1^{\text {st }}$ ed. New Delhi, India: CBS publishers and Distributors, pp: 225-237.

Vanitha, V., Nambi, A.P., Gowri, B. and Karitha, S. (2010). Rumen impaction in cattle with indigestible foreign bodies in Chennai. Tamil Nadu Journal Veterinary and Animal Science. 6 (3): 138-140. 